\title{
PUESTAS EN ESCENA FIN DE SIGLO *
}

\author{
Margarita Almela \\ Universidad Nacional de Educación a Distancia
}

I

\section{PUESTA EN ESCENA. EL CONCEPTO Y SU HISTORIA}

La puesta en escena es la realización concreta, sobre el escenario, de una obra dramática, según un proyecto particular de dirección, con una escenografía, una iluminación, un sonido, un movimiento escénico, una gestualidad, interpretación y figurines, diseñados específicamente para ella en un momento dado.

* Este texto es la adaptación de la conferencia del curso de verano de la UNED, durante la cual se mostraron y comentaron imágenes grabadas de diecinueve puestas en escena. Al desaparecer las imágenes ha sido necesario suplir con descripciones parte de la información, pero aún así es innegable que tales descripciones nunca podrán ser tan eficaces como las imágenes, único medio para hacer evidente parte de lo que se expone. 
De manera que, en ocasiones, el espectador tiene la posibilidad de elegir entre dos espectáculos teatrales con el mismo título, las mismas escenas, el mismo texto, los mismos personajes y, sin embargo, lo suficientemente distintos como para satisfacer demandas muy diferentes y provocar resultados diversos (piénsese en los diferentes montajes de una misma obra de García Lorca que el 98 nos ofreció).

El autor literario maneja palabras e ideas, sugiere espacios, estados de ánimo, estaciones del año, pero alguien ha de interpretar todo esto, hacerlo realidad, una realidad ficticia e irrepetible.

Max Herman ${ }^{1}$, ya en 1914 estableció la diferencia entre «drama» y «teatro», considerando que el primero es un «género literario que utiliza la conjunción de diálogos y didascalias y una específica articulación de espacios y tiempos. En tanto que literatura, su expresión y difusión se realiza a través de medios impresos (...) que garantizan tanto su existencia como conservación. Existe un autor definido, individual o colectivo de estos textos, con personalidad jurídica propia.» Mientras que por teatro se entiende «una forma de expresión artística autónoma que articula una compleja gama de sistemas y medios de significación: verbales, gestuales, rítmico-dinámicos, espacio-visuales, sonoros, luminosos, etc., relacionados e interdependientes entre sí. La producción y difusión del hecho teatral se realizan en un espacio y tiempo concretos en el que coinciden quienes crean y quienes reciben».

A partir de Herman fue separándose la historia de la literatura dramática de la historia del hecho teatral, aunque en España haya costado mucho más tiempo llegar, incluso, a plantearlo, y no me atrevería a decir que el tema está zanjado.

A esta diferenciación o separación contribuyeron el nacimiento y desarrollo de «nuevas» disciplinas, como la Estética del Teatro, la Teatrología, la Dramaturgia y la Semiótica, que aportaron unas metodologías específicas de estudio y cambiaron criterios y elementos valorativos del teatro.

Pero así como la figura del autor dramático es tan antigua como la historia de la literatura dramática, hasta finales del siglo XIX no comienza a definirse la figura del director de escena tal como hoy la

1 Estudios sobre historia del teatro alemán de la Edad Media y el Renacimiento, 1914. 
entendemos, como un profesional que coordina las distintas instancias creadoras que confluyen en el espectáculo.

Es el reconocimiento de esta profesión lo que propicia la aparición de un nuevo concepto ligado a ella, el de «puesta en escena» (del francés mise en scène), entendida como una organización de los materiales escénicos, en un espacio y tiempo concretos, y con una intencionalidad ideológica y estética definidas.

En los primeros 25 años del siglo XX, la obra de teóricos como Stanislavski, Meyerhold, Reinhardt, Copeau, Jouvet, Jesner, Piscator, Dullin, Tairov, Craig, Appia, etc., acaban por imponer una realidad que hoy nos parece un hecho natural.

Fue en 1913 cuando se reunieron por primera vez, en Berlín, los cuatrocientos directores teatrales que componían la primera Asociación de Directores Artísticos de Escena y plantearon un tema insólito entonces: la autoría de la puesta en escena y, por tanto, la exigencia de los derechos de autor de la misma.

A mitad del siglo XX se reconoció en Europa el derecho legal de la puesta en escena, pero 75 años después de aquel primer congreso de Berlín, en 1988, se reunió en el Teatro Principal de Palma de Mallorca el Primer Congreso de la Asociación de Directores de Escena de España, cuya ponencia marco volvía a plantear (bien que por primera vez en España) la problemática de la autoría de la puesta en escena, reivindicada por los directores de teatro.

La larga historia del enfrentamiento entre autores dramáticos y directores de escena ha llevado, en algunos casos, a la radicalización de las posturas conduciendo, por un lado, a los primeros, a proclamarse autores y dueños absolutos de la obra, y a los segundos a considerar a aquéllos como meros «libretistas».

Ángel Facio llegó a decir en este Primer Congreso de la $\mathrm{ADE}^{2}$ :

\begin{abstract}
El teatro no se escribe, el teatro se hace. Lo que se escribe es la literatura (...). Los que escriben se las tienen que ver con la palabra, los que hacemos teatro con la conducta. (...) [Lo que hace el director de escena es] inventar un lenguaje escénico, manejar la propuesta literaria, como el ceramista maneja el caolín, el pintor el óleo o la acuarela, o el músico las notas de la escala.
\end{abstract}

2 Ángel Facio, «Autoría, condición social y problemática laboral», en Hormigón (1989: 34-38). 
Pero dejando a un lado radicalismos, es lo cierto que los directores con quienes he tenido ocasión de tratar siempre consideran el texto dramático como «un elemento más y no único en el hecho teatral»; un elemento, además, perfectamente manipulable porque permite una lectura personal en la que se potencian unos compentes $u$ otros en función de cada lector, es decir, de cada director ${ }^{3}$.

La labor del director de escena consiste, por tanto, en comprender $y$ traducir la literatura dramática: leer palabras y soñar imágenes, «hacer que los demás creen en público (siempre en público, ante un público), imágenes que él mismo ha soñado» ${ }^{4}$, y que, a veces, coinciden con las del autor de las palabras.

\section{LA PUESTA EN ESCENA HOY}

En este siglo que acaba los avances tecnológicos, los cambios estéticos, los hábitos creados en el espectador por el mensaje publicitario, etc., han hecho cambiar radicalmente la puesta en escena. «Trabajar como antaño es condenarse al anacronismo, ignorar la tecnología es dormir en la ignorancia, y confiar en un teatro exclusivamente discursivo es hacer el ridículo», decía hace once años Agustín Iglesias ${ }^{5}$, pero aún hay directores anclados en el pasado y autores que se resisten a las propuestas de los directores.

Los autores dramáticos - como les ocurre también a los novelistas cuando una obra suya es llevada al cine-, consideran habitualmente, en el caso de estar disconformes con una puesta en escena, que les han destrozado la obra, porque no la han respetado, porque la han tergiversado, etc. $Y$ es cierto que en muchos casos todos hemos sido de esta opinión ante un determinado montaje teatral. Pero no siempre el autor tiene razón. Porque una puesta en escena, como hemos sugerido ya, es una de las lecturas posibles de la obra. Lo que ocurre es que en una lectura silenciosa e individual, cada uno de nosotros crea en la mente unas imágenes a partir de las palabras, que a menudo no comunicamos y

3 Consuelo Recio, directora teatral, en el debate de la ponencia de A. Facio. Ver Hormigón (1989: 46).

4 Jaume Melendres, «Técnica y estética de la escenificación», en Hormigón (1989: 54).

5 Agustín Iglesias, «Ética y simulacro de la puesta en escena», en Hormigón (1989: 56). 
casi nunca conoce el autor $o$, de lo contrario, protestaría en gran parte de los casos.

Si el acto de leer supone necesariamente una actualización -al establecerse el diálogo entre la obra y el lector-, en el caso del teatro una lectura no puede limitarse a «reproducir las relaciones entre el texto y sus condiciones históricas concretas de representación», porque entonces sólo sería posible innovar en las puestas en escena de muy contadas obras de autores vivos que incorporaran a su texto las últimas tendencias estéticas y las más avanzadas tecnologías. Si esto hubiera sido así, el desarrollo del arte escénico se habría limitado considerablemente y gran parte de la literatura dramática sería irrepresentable porque resultaría ajena para el espectador actual ${ }^{6}$.

La puesta en escena, hoy, de una obra dramática, por tanto, comienza por la lectura y análisis del texto, teniendo en cuenta a los espectadores destinatarios. En segundo lugar, la explicitación de la lectura selectiva que de la obra ha hecho el director de escena y su equipo, ha de subrayar las analogías entre el texto y la actualidad contemporánea del espectador, hecho necesario siempre, pero sobre todo cuando el texto no es de absoluta contemporaneidad o pertenece a un autor de distinta nacionalidad. $Y$ este trabajo previo supone ya, necesariamente, una «adaptación», aunque se respete el texto original en su integridad.

Explicaba Juan Antonio Hormigón ${ }^{7}$ que, cuando un director elige una obra del pasado, no lo hace habitualmente sólo por la belleza del texto, sino, y sobre todo, por su vigencia, patente en una lectura «contemporánea», en la que muchas veces, desde la perspectiva actual, cobran protagonismo significados que quedaban más o menos velados en lecturas realizadas en otros momentos de la historia. Otras veces ocurre que un aspecto que no ha sido relevante durante siglos, se valora de pronto de manera distinta y ofrece posibilidades de una puesta en escena que confiera actualidad a la obra, como hacen Laila Ripoll y Miguel Seabra cuando sitúan la historia de Macbeth en un mundo actual de lumpen y mafias ${ }^{8}$; o como hizo María Ruiz cuando llevó de nuevo a los escenarios en 1996 María Estuardo, de Schiller, resaltando

6 Véase Juan Antonio Hormigón, «Del texto al espectáculo. Apuntes para una metodología del trabajo dramatúrgico», en Hormigón (1990: 57-64).

7 Ibid.

8 Puesta en escena de Macbeth, de W. Shakespeare, por Teatro Meridional (Compañía hispano-portuguesa) y Micomicón, bajo la dirección de Laila Ripoll y Miguel Seabra, sobre la traducción y adaptación de Julio Salvatierra, 1999. 
la razón de estado como salvaguarda de la impunidad del poder y el enfrentamiento de dos concepciones del mundo y de la moral encarnadas en dos personajes femeninos ${ }^{9}$.

Una vez hecha y fijada la lectura selectiva del texto comienza el trabajo material de la puesta en escena, trabando todos los segmentos de significación, desde escenografía, luz, sonido y vestuario..., hasta la interpretación, en una estructura coherente que dé soporte a un universo expresivo.

Pepe Sanchis decía con cierta irritación en un debate del Segundo Congreso de la $\mathrm{ADE}$ que hay gente que cree que, por una práctica «aditiva», de añadir focos y millones a una puesta en escena, puede suplirse la absoluta carencia de pensamiento, de reflexión seria y profunda. Y, efectivamente, la experiencia nos demuestra que algunas puestas en escena muy costosas apenas pueden enmascarar la vacuidad de un espectáculo sólo capaz de satisfacer a un público poco crítico, capaz de dejarse seducir por la apariencia formal, pero nunca a un público mejor preparado para entender el teatro.

\section{LA POSTMODERNIDAD}

Hoy nos encontramos en lo que ha dado en llamarse, en todas las instancias culturales, Postmodernidad, y esto afecta, naturalmente, al teatro.

Este concepto ha sido duramente criticado por algunos teóricos en función de una serie de características que le son propias, pero no puede ser negado ni ignorado, y explica algunas tendencias de la puesta en escena de este fin de siglo.

Patrice Pavis, en un trabajo titulado ¿Hacia una puesta en escena posmoderna? ${ }^{10}$, al tiempo que criticaba duramente algunas de sus

9 Puesta en escena de María Estuardo, de Schiller, por el Teatro del Olivar, bajo la dirección de María Ruiz, estrenada en el Festival de Cáceres en el verano de 1996. Véanse, sobre esta obra, Margarita Almela, «El distanciamiento histórico y la crítica del poder. Reflexiones acerca de dos obras teatrales», en José Romera Castillo y F. Gutiérrez (eds.), Teatro historico (1975-1998): textos y representaciones, Madrid: Visor Libros, 1999, 377-388; y Ronald Brouwer, «María Estuardo. Schiller: ¿Clásico, romántico o las dos cosas ?», Primer Acto 265, 1996, 48-50.

10 Publicado por primera vez en España en Boletín $A D E$ 13-14, y recogido en Actas del Segundo Congreso ADE, 1990, 243-50. 
características, las definía con suficiente claridad explicando que lo postmoderno, borra, ignora la historia, porque hemos salido de ella y estamos instalados en la «post-historia»; y que una puesta en escena postmoderna impide una lectura en profundidad, es decir, una lectura histórica de un texto, lo que contrasta absolutamente con lo que acabo de explicar.

Con frecuencia - decía Pavis-, la puesta en escena postmoderna rechaza (...) un texto escrito expresamente para la escena, porque El texto no es ya el sistema tutor primero, ni tampoco el sistema de referencia para juzgar todos los signos de la representación, sino que se convierte en un sistema entre otros.

Mientras que las vanguardias se oponían a la tradición, lo postmoderno no intenta levantarse contra algo u oponerse a algo, simplemente lo ignora y convive con ello. Todo lo que se muestra en escena es sólo un simulacro, es lo falso y la falsa apariencia. No se remite a un signo profundo.

Muy a menudo aparece el empleo de materiales brillantes, superficiales, donde nada rima, de suerte que pudiéramos llamar a esto el fin de la radicalidad, el fin de la negación, la oposición y la polémica.

La idea -continúa Pavis-, es hacer una suerte de eclecticismo, de sincretismo de lenguajes, lo que conduce a una especie de indiferenciación.

Para el postmodernismo ya no existen diferencias entre una obra de Calderón y un canto o una consigna publicitaria porque están tomadas en el mismo plano cultural.

Según las ideas de Pavis, el hombre postmoderno ha perdido la creencia en que el arte, y, por tanto, el teatro, pueda «hablar de la realidad y mucho menos cambiarla». El arte, pues, habría «perdido toda combatividad, toda efectividad». El postmoderno sería, por tanto, «un síntoma de una dificultad de la sociedad occidental de pensar en sí misma, de pensarse a sí misma y de pensar lo que va a ocurrir después y teorizar lo social.»

Otro crítico, Lyotard, en 1987, escribía también sobre el postmodernismo de una manera crítica e irónica ${ }^{11}$, y concluía que «esta ruptura [con el tiempo, con la historia, que supone lo postmoderno] es más bien una forma de olvidar y de reprimir el pasado, es decir, de repetirlo, en vez de una forma de trascenderlo» 12 .

11 En el Magacín Literario de marzo de 1987. Apud Pavis, op. cit.

12 El subrayado es mío. 
No todas estas características pueden observarse en la programación teatral española actual, y en muy pocas puestas en escena confluyen todas. Al contrario, vengo observando en los dos últimos años una tendencia renovada a la crítica del presente, en todas sus facetas, aunque con una fuerte carga irónica, lo que, para algunos críticos, es un signo de postmodernidad. Aunque, bien mirado, la crítica mediante la ironía ha sido siempre una característica de las épocas de crisis y ha prosperado siempre bajo regímenes totalitarios junto con la alegoría.

Es bien sabido que los estudios teatrales, hoy, no pueden dividirse en campos excluyentes, sino que deben abarcar todos los medios, códigos, lenguajes y cuantas unidades de significación pueda contener el hecho teatral. No obstante, dado lo limitado del espacio de que disponemos, y aun partiendo de la idea de que no puede haber espectáculo dramático si no existe antes una obra, una historia, una idea o guión dramático concebido por un autor -o autores-, que motive la puesta en marcha de un montaje teatral, yo quiero centrar la atención sobre todo en los elementos extratextuales de las puestas en escena que voy a mostrar ${ }^{13}$, porque son lo que no se puede ver ni estudiar en los textos dramáticos y son, además, lo que hacen de cada puesta en escena una obra dramática única y singular.

\section{EL ESTUDIO DEL TEATRO. LA MIRADA DEL ESPECTADOR}

Para el estudio del hecho teatral es preciso tener en cuenta una serie de factores «externos» que influyen en la recepción tanto como otros relativos a la puesta en escena propiamente dicha. Así, por ejemplo, la planta de un teatro, su arquitectura, puede influir en la recepción de la obra, porque puede determinar las relaciones que se establecen entre actor y espectador, dependiendo de si el escenario está muy alejado o no de la platea, si tiene o no escalera que los una, si la embocadura es muy pequeña, etc. Se debe observar también si la escenografía subraya o no aspectos insólitos, si la iluminación es plana, cenital, o lateral,

13 Naturalmente esto, aquí, es imposible, y, aunque se han suprimido numerosas referencias y se ha tratado de suplir con la descripción algunos aspectos, el lector que desconozca las puestas en escena aludidas se verá obligado a hacer un esfuerzo adicional. 
y qué efectos produce; si ilumina todo el escenario o deja zonas en sombra... Es a veces muy importante ver si el vestuario corresponde o no al tiempo en que se supone ubicada la obra, si destaca o no la ampulosidad de los gestos del actor... Y en cuanto a la interpretación, independientemente de reconocer o no una determinada escuela interpretativa (método Stanislavsky, Meyerhold, Artaud, Grotowski, etc), resulta muy significativo observar la gestualidad de los actores: si realizan movimientos provocadores del cuerpo, si acompañan la dicción con gestos abiertos o cerrados, si su discurso es articulado o no, etc. Se debe atender también al ritmo y a los elementos coreográficos, porque todo en una representación contribuye al efecto global.

En cuanto al andamiaje conceptual de la puesta en escena, hay que tener en cuenta, en primer lugar, si se trata de una obra de tipo tradicional, con texto preexistente a la puesta en escena; si es una creación individual o colectiva de adaptación de un texto dramático preexistente; o si se trata de una creación sobre una idea o guión de estructura dramática, en la que el texto es creado al mismo tiempo que el resto de lenguajes o elementos.

Y con esto entramos en el análisis de la dirección escénica, donde, como ya vimos, el primer aspecto que habría que tener en cuenta es el enfoque que el director hace de la obra, organizándola según su visión (que puede ser social, política, histórica, etc.), privilegiando siempre algún aspecto (un personaje, un conflicto, una circunstancia), y construyendo, por tanto, una idea que se convierte en eje generador de la puesta en escena. Porque tanto los «contenidos» de las historias dramáticas como el conjunto del hecho teatral, han cumplido a lo largo de la historia unos objetivos sociales: bien sirviendo de apoyo y de propaganda del poder establecido, celebrando sus valores; bien ejerciendo una función de subversión, transgresión y protesta; bien como vehículo de evasión y de diversión, o simplemente cumpliendo unos objetivos de animación social y cultural ${ }^{14}$.

En segundo lugar, habría que atender al estilo artístico predominante: realismo, naturalismo, superrealismo, simbolismo, expresionismo, teatro épico (brechtiano), del absurdo, teatro pánico, etc., en donde interviene poderosamente la labor creadora del equipo artístico, con la escenografía, iluminación, música, coreografía y utillería mayor y menor.

14 Vid. Marco de Marinis (1997: 74-75). 
En el momento actual, una puesta en escena no puede limitarse a «ilustrar» el texto, siguiendo paso a paso las meras necesidades de la acción por él dictada, sino que ha de construir todo un universo de signos en relación dialéctica con dicho texto, capaces de expresar todo su sentido más allá del conflicto de la historia dramática, como apuntaba Francisco Javier ${ }^{15}$. Porque la importancia de la puesta en escena es tal, que en algunos casos puede enriquecer y actualizar una obra clásica sin alterar una sola letra de su texto, cuyo sentido, por la forma en que esté interpretado, puede ser también subrayado o contradicho.

De la dirección escénica depende en última instancia el conjunto de la puesta en escena y, por tanto, la interpretación actoral. Me detendré un momento en un aspecto fundamental de la interpretación en el teatro actual.

\section{LA GESTUALIDAD}

La gestualidad, como cualquier lenguaje, está en gran medida codificada, y el espectador no tiene dificultad, habitualmente, en descodificar este lenguaje plástico, sobre todo cuando el actor recrea la realidad cotidiana con sus gestos, actitudes y movimientos, como ha venido ocurriendo, al menos, desde la comedia burguesa del siglo XVIII. Pero cuando esta gestualidad deja de ser una copia más o menos fiel de la observada y practicada en esa realidad cotidiana, para convertirse en una «re-creación» de la misma y constituirse en un lenguaje metafórico, el espectador puede llegar a sentirse incapaz de reconocer la relación entre los gestos y su significado. Entonces la comunicación puede romperse o no ser plena.

Esto comenzó a ocurrir a principios del siglo XX, cuando un director como Meyerhold, por ejemplo, comenzó a enfatizar los gestos, marcando a los actores actitudes estatuarias, con líneas y formas que se conjugaban con la escenografía. O cuando Antonin Artaud alejó al actor de la realidad cotidiana occidental para hacerlo volver a la etapa primitiva del hombre y expresar así visceralmente sus sensaciones, despojándolas de la ritualidad social reconocible. Y, finalmente, cuando Erwin Piscator y Bertold Brecht, cradores del teatro épico, hacen

15 Cf. Francisco Javier (1984: 61). 
que los gestos del personaje no se correspondan con la situación que vive, sino con la narración que hace de los hechos que ocurren -no que le ocurren- y con la opinión que estos le merecen ${ }^{16}$. Se trata entonces de crear el «gestus social», que sería el resumen de los gestos que cualquier hombre, de cualquier lugar y en cualquier momento realizaría en un mismo contexto y en circunstancias similares.

La gestualidad moderna parte, con pocas excepciones, de estas tres propuestas.

No debo entretenerme en explicar los métodos de Grotowski, Bob Wilson o William Layton, por ejemplo, sólo quiero recordar que en la interpretación actual muchas veces los gestos deben ser comprendidos con un nuevo código, pero éste no tiene univocidad, sino que es la propia obra quien lo debe mostrar, pues los gestos están en función del contexto y el director juega con la intuición del espectador, al cual se invita a penetrar por la vía sensorial más que por la intelectiva, dejándose llevar por lo que ve más que por lo que comprende.

Pero en última instancia, los gestos deben servir para suministrar información. Información que en un teatro de texto debe ser complementaria, aunque a la vez pueda ser contradictoria o entrar en colisión con la información que proporciona el discurso, o el vestido, por ejemplo. En una buena interpretación no puede existir un gesto neutro, ya que un rostro impasible debe significar frialdad, resignación, aburrimiento, etc., en consonancia o contraste con el discurso que se emite.

\section{BREVE APUNTE SOBRE TENDENCIAS ESCENOGRÁFICAS}

Si el barroco del siglo XVII y gran parte de la primera mitad del siglo XVIII potenció la tramoya hasta el extremo de ahogar el texto, algo parecido ha llegado a ocurrir en el siglo $\mathrm{XX}$ con algunas escuelas o tendencias teatrales que, poniendo todo el acento en la escenografía, han ofrecido representaciones en que el texto era una mera excusa; o no se sentía ningún respeto por él o desaparecía.

Por contra, huyendo de las grandes tramoyas y las escenografías grandilocuentes, otra tendencia teatral ha intentado ir hacia el extremo con-

16 Cf. Francisco Javier (1984: 44). 
trario, desnudando escenarios y actores para acentuar el sentido de convención del teatro y rompiendo el juego realista con propuestas basadas únicamente en la expresividad de los actores apoyada por las luces.

Del solo texto a su ausencia, de los rudimentos de la puesta en escena más elemental al barroquismo o la representación ultrarrealista, $-y$, de nuevo, a la desnudez del escenario cubierto por la caja negra donde la expresividad actoral es el único elemento dramático-, el teatro se ha debatido a lo largo del siglo $\mathrm{XX}$ en una búsqueda constante del equilibrio entre texto, actor y espacio escénico, y, en líneas generales, observamos que lo mejor y más representativo del teatro español de este final de siglo ha hecho un esfuerzo por conseguirlo.

\section{II}

La segunda parte de mi exposición está dedicada a comentar una serie de aspectos extratextuales de la puesta en escena, para lo cual he utilizado la programación del Teatro Auditorio Adolfo Marsillach, de San Sebastián de los Reyes, formada por cincuenta y cinco obras, desde junio de 1995 a junio de 1999.

He elegido la programación del Teatro Auditorio Adolfo Marsillach por varias razones. La primera, porque sabía que en él se realizaban grabaciones totales o parciales de las representaciones. En segundo lugar, por haber vivido muy de cerca su arranque y desarrollo; y, por último, por tratarse de un teatro público de gestión municipal, que había nacido como un espacio de exhibición y participación teatral, y, por tanto, ofrecía una programación amplia y representativa, lo que resultaba esencial para mi estudio ${ }^{17}$.

\section{EL TAM}

El Teatro Auditorio Adolfo Marsillach, familiarmente llamado TAM, comienza su andadura el 12 de mayo de 1995, y, desde el principio, se incardinó en la vida cultural del municipio. Sus instalaciones no se

17 Agradezco desde aquí a todas las personas responsables del mismo su ayuda y colaboración. 
limitan a la gran sala de exhibición con su escenario y camerinos, sino que dispone en sus bajos de una pequeña sala con capacidad para cien espectadores, además de una serie de aulas en las que se ubican la Escuela Municipal de Música y el Laboratorio y Taller de la Escuela de Teatro William Layton. Ligada a la primera están la «Joven Orquesta» y la Compañía Infantil de Ópera, y a la segunda la Escuela Municipal de Teatro, donde se imparten clases de interpretación desde los 4 años.

El TAM forma parte tanto de la Red de teatros de la Comunidad de Madrid como de la Red Española de Teatros y Auditorios, pero su programación no se ha limitado a las ofertas de estas redes, sino que, por el contrario, ha ofrecido una muestra muy representativa del teatro más significativo realizado en España durante estos cinco años.

Así pues, este teatro ha sido el lugar de estreno en la Comunidad de Madrid de puestas en escena tan importantes, desde el punto de vista de la calidad artística y la estética, como la obra de La Zaranda Cuando la vida eterna se acabe (14 de febrero de 1998), que no volvió a los escenarios madrileños hasta el otoño siguiente; o el caso de $E l$ Vestidor interpretada por Federico Luppi y Julio Chávez, que hizo su estreno de la gira por España en el TAM (12-2-99) ${ }^{18}$. Otro tanto ocurrió con Salvajes, de José Luis Alonso de Santos, que hizo su pre-estreno en la Comunidad de Madrid en el TAM el 13 de diciembre de 1997, muchos meses antes de que se «estrenase» oficialmente en un escenario madrileño; o Píntame en la eternidad, cuyo autor, Alberto Miralles, eligió este teatro para sus ensayos y estreno absoluto el 18 de abril de 1998, dolido con la actitud de otros teatros madrileños. Y más recientemente, también Ignacio Amestoy eligió el mismo teatro para el trabajo de puesta en escena, ensayos, pre-estreno y estreno de su última obra, Violetas para un Borbón (24-1-99).

En otros casos el TAM ha ido más lejos, entrando a formar parte de la coproducción de obras, como ha sido el caso de la puesta en escena de La tragedia del Rey Ricardo III, de Shakespeare, llevada a cabo por John Strasberg, o Los Enamorados de Goldoni, bajo la dirección de Miguel Narros ${ }^{19}$.

18 Sólo este teatro y el Cervantes de Alcalá de Henares, de entre todos los teatros de la Comunidad de Madrid, quisieron contratar esta obra, perdiéndose así una oportunidad irrepetible para muchos madrileños.

19 Como aquí lo que nos ocupa es el teatro, nada diremos de la danza contemporánea, la cenicienta de nuestros escenarios, excepto que bailarines y coreógrafos como Xevi Muraday, Juan Carlos Santamaría o Teresa Nieto han podido ensayar, montar y estrenar sus espectáculos en la temporada 1998-99. 
Para terminar esta breve presentación del TAM, sólo quiero indicar que, al albergar la Escuela de Teatro William Layton, es un punto de encuentro y de trabajo habitual de gentes de teatro muy representativas, ligadas a esta escuela, como Francisco Vidal, Gerardo Malla, Andrea D'Odorico, José Pedro Carrión, Miguel Narros, Antonio Llopis, Begoña Valle, Alicia Hermida, José Carlos Plaza (quien, por cierto, también montó y ensayó el espectáculo sobre textos de Pessoa que representó a España en la Expo de Lisboa) y tantos otros.

Todo esto hace del TAM un teatro muy especial, y su programación, como puede observarse en la relación que se acompaña como anexo de este trabajo, muestra los criterios de calidad que la han presidido, combinando clásicos y vanguardias, lo más tradicional con lo más innovador, pero apuntando siempre hacia un cierto riesgo que acompaña inevitablemente a lo nuevo.

\section{ALGUNOS ELEMENTOS FUNDAMENTALES DE LA PUESTA EN ESCENA}

\section{El espacio escénico}

En primer lugar hemos de referirnos al espacio dramático, que comprende tanto el lugar desde el que el espectador asiste al acontecimiento teatral, es decir, la platea o patio de butacas, como los dispositivos escénicos, es decir, el escenario, al cual también llamamos espacio escénico.

Esto constituye la arquitectura teatral con la que ha de contar necesariamente el director.

Por mucho que haya evolucionado su concepción y construcción, en todo teatro se dan estas dos partes, correspondientes al mundo de los espectadores y al mundo de la ficción de la obra dramática.

El realismo del siglo XIX es, como todo el mundo sabe, el inspirador de un escenario concebido como una habitación a la que le falta la cuarta pared, por donde los espectadores contemplan, como privilegiados y secretos voyeurs la realidad de unos personajes que tiene 
lugar en esa habitación que reproduce, ilusoriamente, la de la vida real, mediante una escenografía más o menos realista.

Estos dos mundos están, o pueden estar, separados por un tèlón. La existencia o no de un telón corrido cuando el espectador accede a la sala repercute en el grado de ficcionalidad que el director quiere mantener y de la propuesta que hace al público. Por ejemplo, en Violetas para un Borbón, de Ignacio Amestoy, con dirección de Francisco Vidal, el espectador se encontraba al entrar a la sala con un telón descorrido que mostraba un decorado realista en el que una serie de elementos discordantes, como los focos que formaban parte del decorado, rompían el efecto de realismo y proponían el juego explícito de la convención teatral que había de ser aceptada con todas sus consecuencias. Esta propuesta escenográfica de Andrea D'Odorico se avenía perfectamente con la aparición de un personaje como Francesillo de Zúñiga, bufón de Carlos V, en un mundo histórico ubicado en el último tercio del s. XIX.

En cuanto al espacio escénico, diremos, siguiendo a Spang, que puede ser neutro, estilizado o concretado, en función de los tres tipos básicos de decorado: neutro, estilizado y documental o realista.

El espacio neutro es el del escenario vacío, con tan sólo el telón de fondo y los bastidores lisos, para delimitar el espacio escénico, y donde se ponen o quitan objetos de utillería en ocasiones. Esta falta de decorado exige del espectador su colaboración para crear imaginariamente el espacio que sugiere el texto a través del discurso de los actores.

Otra funcionalidad distinta es la que tenía la propuesta de Miguel Narros y D'Odorico en sus Seis personajes en busca de autor, de 1995, donde sí existían decorados sobre un escenario desnudo de telón de fondo y bastidores que permitían al espectador contemplar toda la tramoya y los fondos del escenario al tiempo que el decorado de la obra.

Pero ésa es una propuesta que nos hace D’Odorico habitualmente, que nada tiene que ver con el espacio neutro.

Me explicaba él mismo que en aquella puesta en escena, además de mostrar lo que el espectador no ve nunca en un teatro, se trataba de conseguir la verosimilitud de la acción mediante la utilización de unos elementos antirrealistas. Por ejemplo, el decorado que se monta en escena para que los seis personajes re-presenten su historia está formado por elementos muy elementales, de muy poca altura, inscritos en 
un marco de dimensiones enormes, para conseguir el efecto de que se trata de un ensayo, realmente. En este simulacro de decorado hay una fuente falsa, que, sin embargo, cobra vida, se convierte en real en el momento del suicidio de la niña. Aunque Pirandello no lo explicita, Narros y D'Odorico materializan la presencia del agua que mana porque, si el tiro del niño es real, y produce sangre, el ahogamiento de la niña debía ser «real».

El espacio estilizado supone, naturalmente, un ejercicio de estudio muy minucioso para reducir al mínimo imprescindible los signos teatrales, pues presenta detalles orientativos de la ubicación de la historia, pero sin afán de mímesis realista o naturalista. Los elementos y accesorios son sólo los necesarios para sugerir el espacio o el ambiente en que se desarrolla la acción. Así, en este tipo de escenegrafía, un trono puede representar un palacio real, una mesa de despacho una oficina, una puerta de hierro una cárcel, un banco puede sugerir un parque, un árbol sin hojas que es invierno, etc.

En algún caso, un decorado estilizado puede ser, al mismo tiempo muy complejo. Así, por ejemplo, Rafael Ponce y Gerardo Esteve presentaban en Los hermanos Pirracas en Nemequitepá, sobre el fondo de la caja negra, un decorado con paredes de tela metálica, una gran silla pupitre donde los dos adultos sentados parezcan diminutos, camastros de acero y un gran número de objetos aparentemente superfluos pero funcionales en la acción, cuyo conjunto ofrece una estilización muy desrealizada de cárcel; una cárcel que se asemeja a cualquier ambiente aséptico de arquitectura postmoderna.

Este tipo de decorados estilizados es también el que utiliza una directora como María Ruiz, en cuya María Estuardo la luz y las sombras creaban la ilusión del espacio abierto o cerrado, y una tarima podía ser el trono real o un banco en el jardín, según las escenas. Y lo mismo podemos decir de la escenografía creada por John Strasberg para su Ricardo III, donde una plataforma giratoria con un cofre hace de túmulo funerario, trono real, bodega, cárcel y lo que la escena requiera.

Es evidente que el público ha de colaborar en estas puestas en escena supliendo con la imaginación los elementos omitidos. Y a veces, los directores hacen de la necesidad virtud, haciendo subrayar, mediante la interpretación, el mensaje verbal del drama, y haciendo cobrar a los escasos objetos un valor semántico que perderían en un decorado más prolijo. 
Estas propuestas escenográficas el espectador las percibe como modernas, pero no deben ser muy diferentes de las que usaba el teatro inglés de tiempos de Shakespeare o el español de Lope, donde una silla era un trono y una cruz una iglesia.

Por contra, el espacio concretado utiliza un decorado documental o realista, y pone en juego cuantos elementos y accesorios sirvan para conseguir un grado lo suficientemente alto de verosimilitud o fidelidad a la realidad que trata de reproducir, desde arquitectura hasta vestuario, maquillaje y objetos, con todo lo cual se crea una «ilusión» de realidad. Este tipo de espacio es propio del drama realista del siglo XIX, y del drama burgués del $\mathrm{XX}, \mathrm{y}$ actualmente sigue siendo muy utilizado por los directores del llamado teatro «comercial»: el que se dirige a un público que normalmente no sería capaz de aceptar la convención explícitamente expresada del juego teatral que ofrecen puestas en escena estilizadas o simbólicas.

Éste es el caso que podemos observar en obras como La heredera, de Ruth y Augustus Goetz, dirigida por Gerardo Malla, con escenografía de Félix Murcia y Rafael Palomero, cuyo lujo de decorado y de detalles realistas, como lámparas, puertas, bastidores para el bordado, muebles, paredes enteladas, etc., reproduce un rico salón americano del XIX; todo ello acompañado de un vestuario suntuoso de época, diseñado por Javier Artiñano. Asimismo, el escenario de Magnolias de acero, obra de Josep Massagué, reproduce fielmente un salón de peluquería, con profusión de detalles y elementos «veraces».

Estas dos obras, producidas por Pentacion, han sido dos éxitos comerciales, a lo que ha contribuido, junto a lo conocido de las historias y la elección de los actores, esta escenografía, muy bien recibida por el público. Otra cosa es que estas puestas en escena no supongan ninguna aportación de novedad al teatro español de fin de siglo, ya que se trata de dos adaptaciones de obras cuya popularidad se debe a haber sido llevadas al cine con gran éxito y no aportan ninguna innovación desde el punto de vista escenográfico.

Hay que tener en cuenta también que este tipo de escenografía es generalmente muy costosa, y cuando no se tienen posibilidades de realizarla en unos niveles aceptables de verosimilitud, es preferible renunciar a ella. Y con esto quiero referirme al caso de Mariana Pineda, de Lorca, dirigida por Joaquín Vida, en la que los telones y bastidores pintados simulando muebles, zócalos, ventanas y vigas, si bien podríamos interpretarlos como un deseo de evocar los decorados de la época en 
que la obra se escribió y estrenó, no llegan a conseguir este efecto y, por el contrario, acaban pareciendo una muestra del «quiero y no puedo».

La escenografía documental o realista, puesto que facilita la identificación con la realidad a la que remite, no requiere grandes esfuerzos de interpretación por parte del espectador, como tampoco requiere esfuerzo por parte del escenógrafo y del director para seleccionar elementos significativos de una realidad que se quiere evocar, sino sólo para reproducir esta, es decir, re-presentarla.

No obstante todo lo dicho, un tipo u otro de espacio escénico, independientemente de lo que por sí mismos comuniquen cada uno, pueden ser utilizados para comunicar otro tipo de mensajes, según el conjunto de la puesta en escena, del texto y de la interpretación. Así pues, una escenografía tremendamente realista y documental la encontramos en una obra cuyo autor es lo más alejado de lo que entendemos por comercial y cuyo texto es tremendamente crítico con la realidad del presente. Me refiero a Un día cualquiera, de Darío Fo, en la que su director, Fernando Colomo, con el subrayado de la escenografía de Gabriel Carrascal y de los efectos de la iluminación de Juan Gómez Cornejo, parece buscar una identificación del espectador que haga más eficaz la crítica de ciertos aspectos del mundo contemporáneo que ofrece el texto.

Podríamos decir que existen dos concepciones teatrales opuestas, entre las que se sitúan varios puntos intermedios. Estas concepciones son, la que Spang ${ }^{20}$ llama «ilusionista», que pretende crear un efecto de realidad que consiga la identificación con lo representado, y la «antiilusionista», que intenta conseguir el distanciamiento consciente de la obra dramática, poniendo de manifiesto el carácter de «juego», de convención, de la representación dramática. A la primera correspondería un espacio documental-realista, mientras que la segunda utilizaría unos espacios neutros o estilizados. No obstante el último ejemplo nos demuestra que esto no tiene por qué ser así necesariamente, y que otros elementos contribuyen también a crear el efecto final.

De la correcta utilización de la escenografía depende en muchas ocasiones la recepción de una puesta en escena, pues como conjunto de medios expresivos que comunican, si no están bien utilizados pueden hacer tambalearse la comunicación, es decir, el mensaje que se emite desde el escenario y que el espectador debe descodificar.

20 Kurt Spang (1991). 
Se ha venido diciendo también que existe una fuerte oposición entre espacio único y espacio múltiple, y que, en general, el decorado único suele dar idea de inmovilidad, abulia, rutina y soledad, frente a la multiplicidad de espacios, en la cual puede presentarse, por ejemplo, la oposición dentro/fuera, que ofrece la posibilidad de jugar con las sensaciones de protección, seguridad, orden, paz - de dentro-, en contraposición con el desasosiego, violencia, etc. - de fuera-. O, por el contrario, las sensaciones de opresión y enclaustramiento de dentro se opondrán a la idea de libertad asociada con lo de fuera. No obstante, hoy, razones económicas y de funcionalidad hacen preferibles los decorados únicos, sin que éstos produzcan tales efectos necesariamente.

Un mago de la creación de espacios como es, en mi opinión, Andrea D'Odorico suele utilizar un escenario único, capaz, sin embargo, de representar diversos espacios. Recordemos si no la configuración del espacio creado por él para Violetas para un Borbón, que permite al personaje de la reina $M{ }^{a}$ Cristina figurar que está sentada en el palco del teatro Real contemplando un espectáculo cara al público, mientras que en el mismo escenario, ante ella, separadas las figuras por una balaustrada que parece también delimitar el coro de la capilla, su marido Alfonso XII hace el amor con su amante: la semantización que adquiere el decorado en esos momentos posibilita la doble significación de la escena, pues M. ${ }^{a}$ Cristina contempla a los espectadores contemplando la escena de amor de su marido con su rival, y los espectadores ven a M. ${ }^{a}$ Cristina asistiendo a un espectáculo aludido, que no es otro que un correlato de esa escena de amor, vista por nosotros e imaginada por ella: La favorita de Donizzetti, es decir, la historia de Alfonso XI y su amante Leonor de Guzmán.

El órgano que preside toda la escena es un eje de poder, el de la Iglesia que domina a la monarquía española. Y cuando el decorado se abre, haciendo presente una puerta, se descubre un juego de espejos que revela una realidad compleja: Alfonso XII dominado por las imágenes multiplicadas de las mujeres que rigen su vida.

Este mismo escenógrafo nos ofrecía, en La discreta enamorada, de Lope de Vega, dirigida por Miguel Narros, otro escenario único, cuyos dos niveles espaciales (arriba y abajo), propios de la tradición escénica a la que pertenece el texto, enriquecían enormemente los planos de la acción, marcando las esferas de lo público y lo privado; al tiempo que una sabia utilización de los colores, - como el almagre, acorde así mismo con esa tradición de los corrales de comedia- y un acertado empleo de la luz - de Juan Gómez Cornejo-, multiplicaban los 
ambientes al compás del movimiento escénico de los actores, magistralmente orquestado por Narros.

Hemos de tener presente también que tanto el autor como el director cuentan con el espacio visible del escenario y el espacio aludido y referido de detrás de los telones de fondo, los bastidores y cajas. Este espacio no visible adquiere en algunas obras una expresividad dramática notable.

Un ejemplo muy particular de utilización de este espacio lo ofrece el Ricardo III de Strasberg, en donde existe un espacio intermedio entre el visible y el aludido, ya que algunos personajes hablan entre bastidores, pero no es sólo su voz en off lo que percibimos, sino que, siendo estos bastidores transparentes, al iluminarse permiten ver a las figuras al tiempo que hablan, aunque veladas, como en un sueño. Su presencia es sólo presentida, puesto que no ocupan propiamente el espacio real del escenario.

En Los enamorados de Goldoni, dirigida por Miguel Narros ${ }^{21}$, D'Odorico vuelve a ofrecernos una propuesta de espacio escénico muy particular. En esta obra se ha suprimido gran parte de los bastidores; una plataforma metálica dorada delimita el espacio escénico propiamente dicho, evocador de la comedia dell'arte, pero ésta no ocupa la totalidad del escenario, dejando a su alrededor un espacio intermedio. Además, a la vista del espectador queda, por arriba, parte de la tramoya con los focos, y, a los lados, los fondos del escenario, con su típico desorden. Así pues, puede contemplarse en algunos momentos a un actor sentado a la espera de intervenir en la escena; fuera de ella, por tanto, pero visible para el espectador. Esto tiene especial relevancia en el caso del criado, al cual ven los espectadores contemplar y oír la escena desde fuera. A este criado que, como «todos los criados» que representa, todo lo ve y todo lo oye, lo vemos sonreír irónicamente ante el espectáculo que ofrecen los señores.

$\mathrm{Si}$, como dicen algunos críticos, «el espacio puede ser el reflejo de una determinada ideología o de una actitud psicológica» ${ }^{22}$, éste sería un buen ejemplo.

La idea primigenia de este espacio era la de un escenario vacío, con telón de fondo arquitectónico, como el de algunos teatros venecianos

21 Obra estrenada en el TAM el 19-XII-1998.

22 Spang (1991). 
del siglo XVIII que aún conservan los frescos primitivos. Esta idea de escenario aparentemente desnudo es la que motiva la supuesta visión entre cajas. Los bocetos originales eran de dimensiones aún mayores, acordes con esta estética veneciana, acentuada por el color desvaído, con la pátina del tiempo, de los decorados arquitectónicos. No obstante, la majestuosidad de los decorados definitivos aún hace parecer insignificantes a los seres humanos y sus acciones.

El conflicto actualizado del texto de Goldoni tiene lugar encima de la tarima construida con un material «moderno», contra un fondo desvaído, en ruinas, de la historia pasada que representan los decorados del fondo, que contemplan cómo los efímeros seres humanos repiten incansablemente los mismos conflictos.

En esta tarima hay un constante desplazamiento de las sillas, que actúan como elementos demarcadores del espacio de las escenas, y son los personajes quienes las mueven, llegando a convertirse en un elemento recurrente.

Cuando esta obra se presentó en el Festival de Almagro, el 11-7-99, lo hizo con una escenografía distinta, creada expresamente para el marco arquitectónico que la albergaba, convirtiéndose entonces los decorados teatrales en una prolongación de la arquitectura renacentista del claustro de los dominicos. El ambiente escénico cerrado de la puesta en escena primitiva se abría ahora a un espacio infinito mediante un diorama contra el que se recortaban los arcos, y cuyos matices de iluminación marcaban el paso de las horas del día.

En otras ocasiones, el espacio escénico sale del escenario y se prolongo hacia la platea. Puede ocurrir que las figuras del escenario se dirijan en diálogo directo al público, o que comiencen la actuación entrando en la sala por el patio de butacas. En este caso cuando los espectadores acceden a la sala verán generalmente que una escalera comunica escenario y platea, lo que ya indica que esa comunicación va a producirse.

Tres ejemplos de ampliación del espacio escénico lo ofrecen el Volpo$n e^{23}$, de Ben Jonson, dirigida por Francisco Portes, con escenografía de Lorenzo Collado; Mucho ruido y pocas nueces, de Shakespeare, dirigida por Juan Carlos Coraza, con escenografía de Gerardo Trotti; y 666, de Yllana, dirigida por David Ottone. En el Volpone vemos al personaje de

23 En versión de Enrique Llovet. 
Mosca recorrer a oscuras todo el pasillo central del patio de butacas y ascender por la escalera al escenario, a oscuras también, pero habitado y con el telón descorrido. De lo que ocurre entonces hablaremos luego.

En 666, de Yllana, en un momento dado un personaje escapa del escenario y busca refugio entre el público. La platea se convierte en escenario y los espectadores, en figurantes a su pesar. La provocación del teatro de Yllana coge aquí desprevenido al público, que reacciona, como era de esperar, de forma «pasiva», permitiendo que atrapen al huido y se lleven a cabo la acción que se proponían - ajusticiar al preso-, con la complicidad del público.

Este espectáculo puede considerarse como una muestra del llamado teatro alternativo ${ }^{24}$, donde la gestualidad de los actores, muy expresi$\mathrm{va}, \mathrm{y}$ los sonidos inarticulados pero muy matizados, crean la comunicación del mensaje actoral. Mínimos elementos decorativos y unos pocos accesorios, junto con la luz, crean el ambiente espacial, opresivo y agresivo, contra la caja negra.

Y, por último, la ampliación del espacio escénico abarca tanto el patio de butacas como el vestíbulo del teatro en la puesta en escena de Mucho ruido y pocas nueces. En este caso, el público que iba llegando al teatro era recibido en el vestíbulo por los actores, ya maquillados y ataviados, y era invitado a permanecer allí sin poder acceder al interior de la sala. Cuando el número de espectadores empezó a ser numeroso, los actores comenzaron a desarrollar diversas acciones y diálogos, entre sí y con el público. Los espectadores entraron en la sala ya «entregados»; para asistir al prólogo de la representación.

\section{La iluminación}

La primera función de la luz es la de hacer visible la acción que se desarrolla en el escenario, pero también tiene una segunda función muy importante como indicador del paso del tiempo, tanto de las horas del

$24 \mathrm{El}$ antiguo teatro independiente, tan importante durante la dictadura, se convierte en la democracia - por la moda de cambiar los nombres con la esperanza de cambiar los conceptos que designan-, en teatro alternativo. Este teatro alternativo, como hizo también el independiente, busca nuevas formas expresivas, pero también, como es lógico, reducir los costes de producción, ofreciendo en muchos casos espectáculos de gran calidad sin competir en medios con las grandes producciones. 
día, mediante gradaciones de intensidad y combinación de tonalidades, como de las estaciones del año, pues una luz gris y fría indicaría el invierno y una luz brillante y dorada nos puede indicar que es verano.

En tercer lugar, la luz cumple en la puesta en escena actual una función fundamental: crear espacio. Oscurecer o iluminar una parte del escenario es ya un modo de disminuir o ampliar el espacio escénico. Dejar en las sombras a unos personajes que permanecen en escena es retirarlos de la acción que se desarrolla. Iluminar una parte de un decorado compartimentado es convertirlo en el lugar de la acción. E iluminar el patio de butacas es convertirlo en escenario.

En las puestas en escena actuales la iluminación es un elemento esencial ya que, manejada desde ordenadores y programada, puede ofrecer una gran expresividad, cambiar incluso los colores de las ropas y objetos y crear ambientes sin necesidad de accesorios.

La proyección de la sombra de una cruz sobre el suelo de un escenario puede indicarnos que nos hallamos en el interior de una iglesia, así como la sombra de unas rejas que nos encontramos en una prisión.

En El derribo de Gerardo Malla ${ }^{25}$ vemos cómo la luz y la sombra 26 proyectadas nos indican el abrirse y cerrarse de una puerta y la entrada de un personaje antes de que aparezca en escena, así como nos descubren la presencia huidiza del fantasma de Hamlet tras un telón del decorado mucho antes de que se muestre a los personajes «reales».

En La vida que te di, de Pirandello, dirigida por Narros, la iluminación de Juan Gómez Cornejo contribuye a la caracterización de los personajes, pues el hijo muerto se hace visible en un ambiente desrealizador creado por la luz a través de un bastidor iluminado y transparente, así como la luz que sale de una puerta situada a la izquierda del espectador marca el espacio aludido, y presentido, de la muerte. En esta obra, la silueta de la luna, producida también por un efecto de iluminación, ubicada dentro del espacio de la casa, de paredes elevadísimas y sin techo, crea la ambigüedad entre el espacio exterior y el interior. En esta escena se enfrentan la madre tierra y la luna, evocando, además, el mito de Yocasta y Edipo, presente en toda la obra. El ser humano en medio de un decorado de dimensiones grandiosas evoca la impotencia de unos seres que nacen y mueren en un macrocosmos que no controlan.

25 Dirigida por él mismo.

26 Iluminación diseñada por Josep Solbes. 
En Ricardo III se utiliza la luz, diseñada por Rafael Echeverz, para otorgar a las figuras un carácter siniestro, a lo que contribuye también el color oscuro de todo el decorado, de John Strasberg, y los contrastes del vestuario de Sonia Grande. Al tiempo, como ya indiqué, al iluminar los espacios entre cajas transparentes, crea un nuevo espacio escénico intermedio altamente significativo.

Por su parte, Lluís Pasqual, en Como canta una ciudad de noviembre a noviembre, diseña una puesta en escena aparentemente muy sencilla, pero de una perfección muy bien estudiada, donde la iluminación es el elemento principal que concurre a sostener la ilusión de realidad creada por la interpretación de Juan Echanove. En el escenario un piano, una banqueta, unas partituras, una pantalla blanca con una iluminación tenue y amarillenta, a contraluz, un maquillaje caracterizador, no perceptible a simple vista a causa de esa misma iluminación y la gestualidad y voz de un actor crean en el espectador la sensación de estar oyendo y entreviendo a Federico.

Finalmente quiero llamar la atención sobre la utilización de la luz en la primera escena del Volpone. Veremos allí cómo «se hace la luz» obedeciendo a la orden del demiurgo, es decir, Mosca, y con la luz nacerá el escenario, y las figuras, y el movimiento, es decir: el mundo. Aunque sea un mundo de ficción. Este comienzo cuasi bíblico es en mi opinión, uno de los mayores aciertos de esta puesta en escena.

\section{El color}

Y con la luz, el color. Si entre las obras de la programación que me han servido para este estudio hay una que se caracterice por la oscuridad ésta es, sin duda, Ricardo III. El color es un elemento primario de caracterización, y Strasberg ha elegido los tonos oscuros y fríos, con la excepción de los vestidos de las tres mujeres jóvenes. Oscuro es todo el decorado único, oscuro es el entierro del primer acto, y la prisión de la torre de Londres, pero también es oscuro el interior del palacio, y el campo abierto. Todos los personajes masculinos llevan ropas oscuras, pues todos son oscuros, tenebrosos, siniestros y crueles, contra un decorado oscuro. Y ya sabemos que «la figura que siempre se

27 Spang (1991: 172). 
nos presenta en un decorado oscuro y lóbrego acaba "contagiándose", la vemos lucífuga, oculta y retraída» 27

Los colores vivos, acompañados de una luz brillante nos transportarán a un mundo muy diferente y nos liberarán de la opresión de la oscuridad, en comedias; pero que no nos engañe Yllana con sus trajes naranja en 666 , porque se destacan sobre un fondo uniformemente negro.

\section{El sonido y otros elementos}

El sonido es otro elemento cuyas posibilidades han aumentado enormemente en los últimos años, potenciando la expresividad de las puestas en escena.

Las músicas de fondo tienen por lo general como cometido crear una atmósfera acorde con el desarrollo de la acción, pero la presencia de músicos en la escena es ya una llamada de atención hacia un elemento que se quiere destacar y cuya capacidad de comunicación influirá decisivamente en la recepción.

En cuanto a los efectos sonoros, éstos sí son también, y por sí mismos, creadores de espacio. En un escenario vacío o estilizado, los ruidos pueden ofrecer al espectador la información que el decorado no le proporciona, indicándole si se encuentra en campo abierto, en mitad de una calle, etc.

Existen otros muchos elementos expresivos y de caracterización sobre los que no me puedo detener, pero quisiera recordar también que la situación de las figuras en el espacio del escenario lo pueblan, cargándolo de significado, o, retirándose, lo deshabitan, convirtiéndolo en un espacio inoperante. Una figura yendo y viniendo nerviosa por el decorado que figura una celda contribuye a dar sensación de estrechez y enclaustramiento, aunque su espacio ocupe todo el escenario.

Una obra con pocos personajes habitualmente se trata de un drama intimista o de problemática individual, mientras que muchos personajes suelen corresponder a obras que se hacen eco de conflictos sociales y públicos, pero no siempre se da esta regla. Y además un reparto reducido de actores no tiene por qué corresponder a una lista corta de dramatis personae. Cuando Strasberg decide montar Ricardo III con un número reducido de actores que asumen distintos papeles de personajes secundarios, está, por una parte, reduciendo presupuestos, pero 
también acercándose al modo de hacer teatro en la época de Shakespeare. El efecto que consigue con esto, cuando además no hay cambio de vestuario en los personajes secundarios, está motivado por su lectura de esta obra, por su intención de convertirla en un espejo de la violencia del poder. Así, el espectador llega a perder la noción de quiénes son los que realizan las acciones sangrientas, ya no sabe si son los de un bando o los de otro, produciéndose así uno de los efectos buscados: crear en el espectador la idea de que no importa saber quiénes son los personajes, porque el poder, lo ostente quien lo ostente, ejerce la violencia por mano de otros, que siempre son los mismos.

Estos personajes secundarios imponen su presencia al espectador en casi todas las escenas, y siempre son los mismos: los verdugos del poder.

Quisiera también referirme rápidamente a la relación entre objetos y tiempo. Un teléfono de un tipo u otro de diseño, un robot, un microondas en el escenario sitúan la acción en un tiempo más o menos cercano al del espectador, como ocurre, por ejemplo, en Un día cualquie$r a$; mientras un quinqué, una plancha de carbón, una espada o un pergamino lo alejan. Cuando un objeto colocado intencionadamente en un decorado disuena del conjunto produciendo un anacronismo, nos encontramos con varias posibilidades de interpretación: $O$ es un error -que entonces no será el único-, y puede destruir el efecto buscado por la puesta en escena, o se trata de un procedimiento humorístico de distanciamiento o ha sido introducido con una intencionalidad expresiva que puede indicar la vigencia de los conflictos o las soluciones presentados en el drama, y aquí entran, por ejemplo, las gafas de sol que luce Xavier Elorriaga en Ricardo III.

No quisiera terminar sin hacer un breve comentario de la puesta en escena de Bodas de Sangre, de Federico García Lorca, realizada por Francisco Suárez, con escenografía de Jon Berrondo, Iluminación de Juan Gómez Cornejo, vestuario de Maite Álvarez y música de Juan Antonio Suárez.

Esta obra la concibió Paco Suárez como un auto sacramental, con una utilización sistemática de símbolos y alegorías. Tiene el añadido de la música original y en directo y el baile de la Luna, interpretado por la bailarina Merche Esmeralda, además de un prólogo. En ella, la sobriedad de los cuadros realistas contrasta con la exuberancia del cuadro primero del tercer acto, donde el vestuario, el maquillaje, la gestualidad y el baile se conjugan con unos elementos de decorado sumamente ricos y simbólicos, de una belleza fría, que hiere como el 
cuchillo. En un escenario a telón descorrido, presidido por una gran tela blanca, ante la que se sitúan los actores tiene lugar el prólogo, con el recitado de los versos finales de la obra de Lorca, dándole así a ésta un sentido circular. Acaba el prólogo y comienza la acción de la obra con el sonido de un trueno al tiempo que cae al suelo la gran tela blanca, convertida en lluvia por efecto de la luz, presagio de la muerte anunciada en los versos precedentes. Después, la misma tela será la sábana y sudario en una primera escena nuevamente premonitoria, en la que una coreografía que acerca la interpretación actoral a la danza y la música, sumergen al espectador en el universo lorquiano.

Comienzan luego a cobrar vida los decorados, primero estilizados, elementales, y poco a poco cargándose de detalles para pasar gradualmente a una escenografía más realista y concreta, que volverá a romperse en el tercer acto, como ya dije. El juego de estos dos estilos se adapta con singular armonía al texto, que también bascula entre el realismo del drama rural y el surrealismo lírico.

\section{III}

\section{ANEXO}

\section{Programación teatral del Teatro Auditorio Adolfo Marsillach} (no incluido teatro infantil, ni danza ni música)

\section{Por orden cronológico:}

* El asterisco indica las obras de las que se ofrecieron imágenes grabadas.

Woyzech. Autor: G. Büchner. Compañía: A trancas y Barrancas. 17-6-96.

Yo me bajo en la próxima... ¿y usted ? Compañía de Adolfo Marsillach. 20-6-95.

* Seis personajes en busca de autor. Autor: L. Pirandello. Dirección: Miguel Narros. Escenografía: Andrea D'Odorico. Iluminación: Juan Gómez Cornejo. Diseño de vestuario: Miguel Narros. Ayudante dirección: Begoña Valle. Ayudante vestuario: Sonia Grande. Actores: Helio Pedregal, Nuria Galindo, Chema Muñoz, Claudia Gravi, etc. 24 y 25-6-95. 
El Chalet de Madame Renard, Compañía de Elisa Ramírez. 26-8-95.

* La discreta enamorada. Autor: Lope de Vega. Dirección: Miguel Narros. Escenografía: Andrea D’Odorico. Iluminación: Juan Gómez Cornejo. Diseño de vestuario: Miguel Narros. Ayudante de dirección: Begoña Valle. Ayudante de vestuario: Sonia Grande. 8,9 y 10-9-95.

Los domingos matan más hombres que las bombas. 25-11-95.

Trío de dos. Por el Laboratorio Teatral William Layton. 19 y 20-1-96.

Los dioses y los cuernos. Autor: Alfonso Sastre. Producciones « $\tilde{N} » .17-2-96$.

El local de Bernardetta A. Autor: Lourdes Ortiz. Compañía: Fin de Siglo. 9-3-96.

Un celoso extremeño. Autor: Miguel de Cervantes. Compañía: Zascandil Teatro. 30-3-96.

Aspirina para dos (Adaptación de la obra de Woody Allen, Sueños de un seductor). Compañía de Ángel Zorita. 13-4-96

Duelos. Autor: Francisco Prada. Compañía: Fin de Siglo. 25-5-96.

Algo en común. Autor: Harvey Fierstein. Producciones Teatrales Contemporáneas. Dirección: Paco Pino. Escenografía (Realización): Trotti y Asociados. Vestuario: Javier Artiñano. Iluminación: Ana Miguel. Actores: José Coronado, Laura Cepeda, Lola Casamayor, Alejandro Martínez. 8-3-97.

La secretaria. Compañía: Desatino Teatro. 22-3-97.

La profesión de la Sra. Warren. Autor: Bernard Shaw. Traducción: Vicente Molina Foix. Compañía de Julieta Serrano. Director: Calixto Bieito. Escenografía: Mónica Quintana. Vestuario: Mercé Paloma. Iluminación: Javier Clot. Eléctrico: Eduardo Martínez. Actores: Julieta Serrano, Ana Torrent, Miguel Arribas, Alberto Alonso, Andoni Gracia y Francisco Merino. 5-4-97.

Yonkis y Yankis. Autor: José Luis Alonso de Santos. 19-4-97.

* Mucho ruido y pocas nueces. Autor: W. Shakespeare. Traducción original: John Sanderson. Texto Final: Lorena García, Ana Gracia y Alicia Borrachero. Adaptación: Juan Carlos Coraza. Dirección: Juan Carlos Coraza. Coreografía: Denise Perdikidis. Escenografía: Gerardo Trotti. Iluminación: Josep Solbes. Vestuario: Rosa García. Actores: Emilio Línder, Roberto Enríquez, Toni Cantó, Ana Gracia, Paco Olmo, Manuel Morón, Nacho Medina, Antonio Naharro, Paz Gómez, Alicia Borrachero y Mercedes Castro. 17-5-97. 
Una noche con los clásicos. Dirección: Adolfo Marsillach. Músicos: Daniel Carranza y Juan Carlos de Mulder. Dir. de Producción: Jesús Cimarro.

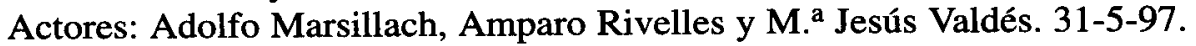

Fankie \&Johnny en el Clair de Lune. Autor: Terrence McNally. Traducción: Roger Peña. Dirección: Mario Gas. Escenografía: Jon Berrondo. Banda sonora y diseño de sonido: José Antonio Gutiérrez. Iluminación: Quico Gutiérrez. Actores: Anabel Alonso y Adolfo Fernández. 28-6-97.

Nuestro querido Chejov. Teatro del Laboratorio William Layton. 25-8-97.

Entremeses. Autor: Miguel de Cervantes. Compañía: Teatro de la Abadía. Dirección: José Luis Gómez y Rosario Ruiz. Escenografía: José Hernández. Espacio Escénico: Rosario Ruiz. Maestría de Movimiento: M. ${ }^{a}$ del Mar Navarro. Iluminación: Juan Gómez Cornejo. Vestuario: M. ${ }^{a}$ Luisa Ángel. 3110-97.

* Bazar. Autor: Daniel Planell. Dirección: Francisco Vidal. Escenografía: Ana Garay. Iluminación: Josep Solbes. Música: Radio Tarifa. Actores: Saturnino García, Alfonso Lara, Gonzalo Gonzalo, Ramos López y Eugenio Vidal. 8-11-97.

Aquellas colinas azules. Autor: Dennis Potter. Dirección: Pilar Massa. Dramaturgia: Ronald Brouwer. Movimiento: Marta Scinca. Escenografía y Vestuario: Ana Llorente. Iluminación: Sergio Oteggui. Música: Gonzalo Alonso. Actores: Borja Elgea, José Luis Patiño, Pedro Miguel Martínez, Jorge Calvo, Ana Otero, Carola Manzanares Gabriel Moreno y la voz de Juan José Otegui. 15-11-97.

Con el amor no se juega. Autor: Alfred de Musset. Versión para la escena: María Ruiz y Ronald Brouwer. Compañía: Teatro del Olivar. Dirección: María Ruiz. Espacio Escénico: María Ruiz. Iluminación: Tom Donnellan. Vestuario: Pepe Rubio. Entrenamiento de actores: César Saratxu. 29-11-97.

Salvajes. Autor: José Luis Alonso de Santos. Dirección: Gerardo Malla. Escenografía: Toni Cortés. Iluminación: Josep Solbes. Composición Musical: Bernardo Bonezzi. Actores: Amparo Soler Leal, Germán Cobos, Beatriz Bergamín, Marcial Álvarez, Aitor Beltrán, Adolfo Pastor, Pablo Rivero y Eduardo Antuña. 13-12-97

Barcelona, París, Caracas. Chicos Mambo Show. Autores: Chicos Mambo Show. Vestuario: Chicos Mambo Show. Iluminación: Peni Barratxina y Amadeu Solernou. Banda Sonora: Chicos Mambo Show. Actores: Chicos Mambo Show: Martí Boada, Xavier Estrada y Philippe Lafeuille, Xevi Dorca y la voz de Toni Martínez. Producciones Teatrales Contemporáneas (Ana Jelín). 17-1-98. 
* La dama boba. Autor: Lope de Vega. Versión de Daniel Pérez Fernández. Compañía de Teatro Nuevo «Replika». Director: Jaroslaw Bielki. Escenografía y Vestuario: Agatha Ruiz de la Prada. Iluminación: Camilo Gutierrez. Actores: Soledad Mallol, Elena Martín, Fernando Huesca, Julio César

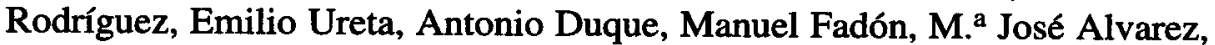
Paca Mencía. etc. 31-1-98.

Cuando la vida eterna se acabe. Autor: Eusebio Calonge. Compañía: La Zaranda. Teatro Inestable de Andalucía la Baja. Dirección: Paco de la Zaranda. Escenografía: Paco de la Zaranda. Iluminación: Eusebio Calonge. Vestuario: Teatro La Zaranda. Sonido: Eusebio Calonge. Actores: Francisco Sánchez, Gaspar Campuzano, Enrique Bustos y Fernando Hernández. El Foro Espectáculos (Ramón Remesal). 14-2-98

* La Heredera. Autor: Ruth y Augustus Goetz. Versión: Enrique Llovet. Dirección: Gerardo Malla. Escenografía: Félix Murcia y Rafael Palomero. Iluminación: Josep Solbes. Vestuario: Javier Artiñano. Música: Bernardo Bonezzi. Producción: Pentación. Jesús Cimarro. Actores: Sandra Toral, Carmen de la Maza, Víctor Valverde, Antoni Ferreño, etc. 28-2-98.

* La vida que te di. Autor: L. Pirandello. Compañía de Andrea D'Odorico. Director: Miguel Narros. Escenografía: Andrea D'Odorico. Iluminación: Juan Gómez Cornejo. Vestuario: Miguel Narros. Actores: Margarita Lozano, Fabio León, M. ${ }^{a}$ Alfonsa Rosso, Margarita Mas, Paco Torres, Claudia Gravi, etc. 21-3-98.

* Pintame en la eternidad. Autor: Alberto Miralles. Director: Gerardo Malla. Escenografía y vestuario: Ana Garay. Iluminación: Rafael Echeverz. Actores: Gerardo Malla, Manuel Galiana, Cipriano Lodosa, Carmen Martínez. Obra ensayada en el Teatro Auditorio Adolfo Marsillach y estrenada en el mismo: 18-4-98.

La balada de los tres inocentes. Autor: Pedro M. ${ }^{a}$ Herrero. Compañía: Respira Teatro. Director: José Luis Saiz. Escenografía: Alfonso Barajas. Iluminación: Josep Solbes. Actores: Fernando Guillén, María Asquerino, José Luis Sáiz. 25-4-98.

* Magnolias de acero. Autor: Robert Harling. Versión: Diana Laffond Yges. Dirección: Ricard Reguant. Escenografía: Josep Massagué. Iluminación: José Manuel Guerra. Producción: Jesús Cimarro. Actores: Beatriz Carvajal, Cristina Higueras, Charo Soriano, Eva Santa, Mabel Karr y Xana. 305-98.

* Lobas y zorras. Historias para enrojecer. Autor: Francisco Nieva. Compañía Geografías Teatro. Dirección: Juanjo Granda. Escenografía: Gerardo 
Trotti. Vestuario: Sonia Grande. Música: Javier Balboa. Coreografía: Blanca Calvo. Actores: Isabela Ayúcar, Janine Mestre, José Olmo, Vicky Lagos, etc. 6-6-98.

* Un día cualquiera. Autores: Franca Rame y Darío Fo. Traducción-adaptación: Carla Matteini. Dirección: Fernando Colomo. Escenografía y vestuario: Gabriel Carrascal. Iluminación: Juan Gómez Cornejo. Vestuario: Gerardo Trotti. Producciones Teatrales Contemporáneas. Actores: Anabel Alonso y la voz de Julieta Serrano. 13-6-98.

Meli-Melo. Chicos Mambo Show. Idea-Guión: Chicos Mambo Show. Director: Oscar Molina. Iluminación: Sam Lee. Vestuario: Ramón Ivars, Marco y Alex, Alex Tarragüell. Banda Sonora: Chicos Mambo Show. Coreografía: Chicos Mambo Show. Actores: Martí Boada, Xevi Dorca, Xavi Estrada, Philippe Lafeuille. 29-8-98.

* La tragedia del rey Ricardo III. Autor: W. Shakespeare. Traducción: John Sanderson. Versión: John Sanderson. Dirección: John Strasberg. Escenografía: John Strasberg. Iluminación: Rafael Echeverz. Vestuario: Sonia Grande. Música: Mariano Díaz. Actores: José Pedro Carrión, M. ${ }^{a}$ Luisa San José, Cristina Marcos, Xavier Elorriaga, Maruja Boldoba, Alfredo Alba, Julio César Rodríguez, Gonzalo Gonzalo y Carlos Moreno. Obra coproducida por el Teatro Auditorio Adolfo Marsillach, ensayada y estrenada en el mismo teatro: $26-9-98$.

* Yllana 666. Autor: Yllana. Dirección: David Ottone. Iluminación: Juanla Martín. Vestuario: Teresa Rodrigo y Jesús Povedano. Sonido: Yllana y Pelayo Gutiérrez. Actores: Juan F. Ramos, Joe O'Curneen, Raúl Cano y Fidel Fernández. Estreno en la Comunidad de Madrid: 9-10-98.

* Mariana Pineda. Autor: F. García Lorca. Dirección: Joaquín Vida. Escenografía: Juan Vida. Iluminación: Carlos Moreno y Joaquín Vida. Vestuario: Joaquín Vida. Música: Manuel Balboa. Actores: Carmen Conesa, Manuel Bandera, José María Hinojosa, M. ${ }^{\mathrm{a}}$ Paz Ballesteros... Estreno en la Comunidad de Madrid: 30-10-98.

* Como canta una ciudad de noviembre a noviembre. Autor: F. García Lorca. Director: Lluis Pasqual. Escenografía: Teatre Lliure. Iluminación: Lluis Pasqual. Vestuario: Teatre Lliure. Música: Josep Maria Arrizabalaga. Actor: Juan Echanove. 7-11-98.

* Volpone. Autor: Ben Jonson. Versión: Enrique Llovet. Compañía: Francisco Portes. Dirección: Francisco Portes. Escenografía: Lorenzo Collado. Actores: Francisco Portes, Francisco Vidal, Alejandra Torray, Alfredo Alba, Servando Caballar, Pablo Isasi, Marisa de Leza... 13-11-98. 
* Bodas de Sangre. Autor: F. García Lorca. Director: Francisco Suárez. Escenografía: Jon Berrondo. Iluminación: Juan Gómez Cornejo. Vestuario: Maite Álvarez. Música: Juan Antonio Suárez. Actores: Lola Cardona, Alicia Hermida, Paulina Gálvez, Roberto Enríquez, José V. Moirón, Alicia Sánchez y Merche Esmeralda. 21-11-98.

* El derribo. Autor: Gerardo Malla. Director: Gerardo Malla. Escenografía: José Luis Raymond. Iluminación: Josep Solbes. Música: Miguel Malla. Actores: Francisco Casares, Luisa Martínez Pazos, Manuel de Blas, Ana M. ${ }^{a}$ Barbany, Pepe Martín. 12-12-98.

* Los enamorados. Autor: Carlo Goldoni. Dirección: Miguel Narros. Ayudante de Dirección: Begoña Valle. Escenografía: Andrea D'Odorico. Iluminación: Juan Gómez Cornejo. Vestuario: Miguel Narros. Asesor Musical: Víctor Pagán. Obra Coproducida por el Teatro Auditorio Adolfo Marsillach, ensayada y estrenada en el mismo: 19-12-98.

Violetas para un Borbón (La Reina Austriaca de Alfonso XII). Autor: Ignacio Amestoy. Director: Francisco Vidal. Escenografía: Andrea D'Odorico. Iluminación: Rafael Echeverz. Vestuario: Sonia Grande. Actores: Francisco Merino, Teresa J. Berganza, Juan Gea, Ana Frau, Claudia Gravi. Estreno Nacional: 24-1-99.

El Vestidor. Autor: Ronald Harwood. Director: Miguel Cavia. Escenografía y vestuario: Andrés Díaz Mendoza. Iluminación: Gabriel Cavia. Actores: Federico Luppi, Julio Chávez, Beatriz Spelzini, Elvira Onetto, Jorge Ochoa y Mariel Ortiz. Estreno en España: 12-2-99.

Klowns. Idea y Guión: Joan Montanyès y Josep M. ${ }^{a}$ Mestres. Director: Josep M. ${ }^{a}$ Mestres. Actores: Mónica Alsina, Oriol Boixader, Andreu Bresca, Esteve Ferrer, Jordi Martínez, Joan Montanyès y Borja Sagasti. 27-2-99.

Las presidentas. Autor: Werner Schwab. Dirección: Carme Portacelli. Escenografía y vestuario: Gina Cubelles. Iluminación: María Doménech. Actrices: Lourdes Barba, Mercé Aranega, Lina Lambert. 6-3-99.

Clasyclos (Comando Incontrolado de Teatro). Autor: Juan Margallo. Director: Juan Margallo. Escenografía: UROC Teatro. Iluminación: Rafael Catalina. Vestuario cedido por el Centro Dramático Nacional de Teatro Clásico. Música original: Theodora Carla. Actores: Vicente Cuesta, Juan Margallo, Petra Martínez y Theodora Carla. 13-3-99.

El sueño de una noche de verano. Autor: W. Shakespeare. Dirección y Adaptación: Eva del Palacio. Escenografía: Eva del Palacio y Fernando Aguado. Iluminación: Guillermo Erice. Vestuario: Eva del Palacio y Fernando 
Aguado. Maquillaje, máscaras y caracterización: Álvaro Aguado y Fernando Aguado. Música original: Carlos Pérez Mántaras. Magia: Willy Monroe. Actores: Fernando Aguado, Marina Andina, Álvaro Aguado, Carol Garrigues, Carmen Godiy, Miguel Armayor, Pedro Olivera y Javier Botella. 26-3-99.

Los Hermanos Pirracas en Nemequitepá. Autor: Rafael Ponce. Director: Esteve y Ponce. Escenografía: Carles Alfaro. Iluminación: Carles Alfaro y Ximo Díaz. Vestuario: La compañía. Actores: Gerardo Esteve y Rafael Ponce. 17-4-99.

Las últimas lunas. Autor: Furio Bordon. Adaptación: Rafael Azcona. Director: José Luis García Sánchez. Escenografía y vestuario: Ana Garay. Iluminación: José Manuel Guerra. Actores: Juan Luis Galiardo, Carmen Conesa, Luis Perezagua. 24-4-99.

Macbeth. Autor: W. Shakespeare. Adaptación y traducción: Julio Salvatierra. Teatro Meridional (Compañía hispano-portuguesa) y Micomicón. Dirección: Laila Ripoll y Miguel Seabra. Escenografía e Iluminación: Laila Ripoll y Miguel Seabra. Vestuario: Elisa Sanz. Música original: Juan Carlos Torres. Actores: Filipe Duarte, Álvaro Lavín, Mariano Llorente, Inma Nieto, Óscar Sánchez Zafra, José Luis Patiño y Manuela Pedroso. 8-5-99.

La opinión de Amy. Autor: David Hare. Adaptación: Juan José de Arteche. Director: Ángel García Moreno. Escenografía: Toni Cortés. Iluminación: José Luis Rodríguez. Actores: Ángeles Martín, Amparo Baró, Miguel Pérez Meca, Elvira Travesí, Fernando Delgado y Miguel Such. 23-5-99.

La vida es sueño. Autor: Pedro Calderón de la Barca. Teatro Fin de Siglo. Versión y dirección: Javier Garcimartín. Actores: Miguel Hermoso, Lorena Piorno, Janfri Topera, Gloria Aboy, Celia Fernández, Francisco Maestre, Javier Urquidi, Jesús Laguía, Álvaro Moyano y Daniel Monterroso. 6-6-99.

\section{Referencias bibliográficas}

\section{Libros}

ARIAS DE Cossio, Ana M. ${ }^{a}$. (1991). Dos siglos de escenografía en Madrid. Madrid: Mondadori.

BALlús, Carme (1993). La renovació teatral al segle XX. Barcelona: Barcanova. 
BATISTE, Jaume (1991). La escenografía: esquemas del autor. Barcelona: La Galera.

BERENGUER, Ángel (1991). Teoria y crítica del teatro: Estudios sobre teoría y crítica teatral. Alcalá de Henares: Servicio de Publicaciones de la Universidad.

BrooK, Peter (1986). El espacio vacío. Barcelona: Península.

CANFIELD, Curtis (1991). El arte de la dirección escénica. Madrid: Publicaciones ADE, 2. ${ }^{\mathrm{a}}$ ed. 1995.

CENTENo, Enrique (1996). La escena española actual (Crónica de una década: 1984-1994). Madrid: SGAE.

CluRMan, Harold (1990). La dirección teatral: Notas sobre la puesta en escena. Buenos Aires: Grupo Editor Latinoamericano.

FrTE, Salvador (1992). La dirección escénica. Barcelona: La Galera.

GROTOWSKI, Jerzy (1992). Hacia un teatro pobre. Madrid: Siglo XXI.

GUTIÉRREZ, Fabián (1993). Teoría y praxis de semiótica teatral. Valladolid: Secretariado de Publicaciones de la Universidad.

HeLBo, André (1983). Les mots et les gestes. Essai sur le théâtre. Lille: Presses Universitaires de Lille.

- (1987). Théatre. Modes d'approche. Bruxelles: Labor.

- (1989). Teoría del espectáculo. El paradigma espectacular. Buenos Aires: Galerna.

Hormigón, Juan Antonio (ed.) (1989). Primer Congreso de la Asociación de Directores de Escena. Madrid: Publicaciones ADE.

- (ed.) (1990). Segundo Congreso de la Asociación de Directores de Escena. Madrid: Publicaciones ADE.

- (1991). Trabajo dramatúrgico y puesta en escena. Madrid: Publicaciones ADE.

- (ed.) (1992). V. S. Meyerhold: Textos teóricos. Madrid: Publicaciones ADE.

JAVIER, Francisco (1984). Notas para la historia científica de la puesta en escena. Buenos Aires: Leviatán.

KowZAN, Tadeusz (1992). Literatura y espectáculo. Madrid: Taurus.

MARINIS, Marco de (1997). Comprender el teatro. Lineamientos de una nueva teatrología. Buenos Aires: Galerna.

Oliva, César y TORRes MonReAL, Francisco (1990). Historia básica del arte escénico. Madrid: Cátedra.

Pavis, Patrice (1990). Diccionario del teatro: Dramaturgia, estética, semiología. Barcelona: Paidós Comunicación.

- (1994). El teatro y su recepción. Semiologia, cruce de culturas y posmodernismo. La Habana: UNEAC-Casa de las Américas.

SPANG, Kurt (1991). Teoría del drama. Lectura y análisis de la obra teatral. Pamplona: EUNSA.

StANISLAVSKI, Constantin (1990). El arte escénico. Madrid: Siglo XXI.

TEIXIDOR, Jordi (1989). El drama, espectacle i transgressió: elements de dramatúrgia teórica. Barcelona: Institut del Teatre. 
TrAPERo Llobera, Patricia (1989). Introducción a la semiótica teatral. Palma de Mallorca: Prensa Universitaria.

UbERSFELD, Anne (1990). Semiótica teatral. Madrid: Cátedra.

- (1997). La escuela del espectador. Madrid: Publicaciones ADE.

VV.AA. (1988). Elementos para una semiótica del texto artístico. Madrid: Cátedra.

\section{Revistas}

- ADE. Teatro.

- Cuadernos de Dramaturgia Contemporánea.

- Cuadernos de Teatro Clásico, $\mathrm{n}^{\circ}{ }^{8} 8,1995$, «La puesta en escena del teatro clásico».

- Escena.

- Gestos.

- Primer Acto.

- Teatro. 